\title{
CULTURAL AND LEISURE CLUSTERS IN GREEK CITIES: SPONTANEOUS FORMATION AND 'LAISSEZ-FAIRE' DEVELOPMENT
}

\author{
A. GOSPODINI \\ Department of Planning and Regional Development, University of Thessaly, Volos, Greece.
}

\section{ABSTRACT}

This article is concerned with cultural economies in the post-industrial city and examines the phenomenon of cultural and leisure clusters in Greek cities. In the first part, the article discusses the key role of cultural economies in the post-industrial city and presents types of cultural clusters in inner city areas. The second part focuses on Greek cities and analyses three cultural and leisure clusters in Athens, Thessaloniki and Volos. The article documents the spontaneous formation and the 'laissez-faire' development of such clusters; it records the shift of land uses and the transformations of urban landscape, and also highlights the urban policies involved. Finally, it draws conclusions on the formation and management of cultural and leisure clusters, especially the differences among large cities in the core of Europe and large Mediterranean cities in the developing periphery of Europe.

Keywords: cultural and leisure economies, Greek cities, post-industrial city, spontaneous clusters, urban landscape transformations.

\section{CULTURAL ECONOMIES AND CULTURAL AND LEISURE CLUSTERS IN THE POST-INDUSTRIAL CITY}

Through out urban history, cities have always exhibited a capacity to act as centres of cultural activities and generate culture in the form of various arts and styles, new ideas and attitudes. However, since the 1990s, the post-industrial city is witnessing an accelerating pace of growth of cultural and leisure economic activities. In the new milieu of economic globalisation and volatility of capital and enterprises, the relocation of traditional industries in developing regions was accompanied by an unprecedented growth of cultural and leisure industries in mature cities. Production and consumption of culture and leisure (arts, fashion, music, food, tourism) and the industries that cater to it, along with 'creative industries' containing design (in architecture, fashion, graphics, internet, etc.), have become the growth engine of the post-industrial city [1-7]. As argued by Sir Peter Hall [7], cities have passed at extraordinary speed from a manufacturing to an informational economy and from an informational economy to a cultural economy; and 'culture is now seen as the magic substitute for all the lost factories and warehouses, and as a device that will create a new urban image, making the city more attractive to mobile capital and mobile professional workers' ([7], p. 640).

A large number of studies have measured particular parameters and analysed different sectors of the cultural and leisure urban economies [5-11]. Scott [5,6] interprets the accelerating pace of growth of cultural industries as a result of both the increasing disposable consumer income and the discretionary time of the middle classes in developed countries. On the same line, Nichols Clark [12] describes an emerging amenity urban growth - both economic and demographic - rooted in the fact that educated and talented young professionals and high-tech staff, who can locate themselves where they choose, are mainly courted by cities that compete for them with public amenities. Thus, for Nichols Clark, leading urban policies are now passing from the provision of larger incentives to enterprises than the competing locations to the provision of lifestyle amenities for visitors and mainly for residents [12].

(C) 2007 WIT Press, www.witpress.com

ISSN: 1743-7601 (paper format), ISSN: 1743-761X (online), http://journals.witpress.com DOI: 10.2495/SDP-V2-N2-119-133 
The post-modern accelerating pace of growth of cultural and leisure economic activities in cities has been accompanied by a parallel strong proclivity to clustering: Before the 1990s, cultural buildings and building complexes, even those representing big architectural statements and flagship projects like for instance, President's Mitterand 'Grands projets' in Paris, were more or less randomly distributed over the plan of the inner city - perhaps realising some small and ad hoc local concentrations. Since the 1990s, as Mommaas [13] argues, cultural clustering represents the next stage in the ongoing use of culture as a growth engine in urban economy, 'a shift from a policy aimed at organising occasions for spectacular consumption to a more fine-tuned policy, also aimed at creating spaces, quarters and milieus for cultural production and creativity' ([13], p. 508, my emphasis). A significant such case is the Museum Quarter in Vienna that consists of 20 museums and cultural institutes covering a surface of $60,000 \mathrm{~m}^{2}$. A large part of it is developed on a site where the royal horse stables, in baroque style, were initially built in the 18th century. The site was reused as a trade fair in 1918, and since the 1990s it has been gradually redesigned and redeveloped as Vienna's main cultural district that has incorporated pre-existing cultural buildings such as the Historical Museum, the Natural History museum, Hofburg and Neue Burg. New buildings, such as Momuk (Museum Modern Kunst), have been added to the old building complexes. The official opening of the Museum Quarter was in 2001.

Evidence to the trend of clustering of cultural and leisure economic activities is a growing number of studies on various kinds of such clusters - for instance, clusters of television and film making [14-16], clusters of leisure and night-time economy [10,11, 17, 18], clusters of fashion design $[19,20]$, and clusters of ethnic restaurants and ethnic fashion [21].

In some cases, clusters of cultural and leisure activities are spontaneously created due to the advantages and economic benefits produced by spatial neighbouring. These advantages and benefits may be conceived in relation to the particularities of cultural industries in terms of production relations and distribution methods, as described by Scott [5]: Labour processes in cultural industries involve considerable amounts of handiwork complemented by computer technologies; production is organised in dense networks of medium- to small-sized establishments strongly dependent on one another for specialised inputs and services; these networks form multifaceted industrial complexes that may reduce for both employers and employees the risks deriving from frequent recurrent job search; cultural industries are invariably replete with external economies, many of which can only be effectively appropriated via locational agglomeration, which gives rise to mutual learning and cultural synergies; agglomeration also facilitates the emergence of institutional infrastructure that can ease the functioning of local economy ([5], p. 333).

But in most cases, culture and leisure clusters are stimulated, encouraged, and planned by the public sector and the city's authorities. This is rooted to the fact that clustering of cultural and leisure activities may work as a catalyst to processes of urban redevelopment and renewal in declined and underused inner city areas - mostly former industrial areas. The phenomenon of culture-led regeneration of inner city areas has produced new urban forms and landscapes that constitute signifying precincts or epicentres in the post-industrial inner city [22,23].

According to Hutton [22], 'signifying precincts' of new urban economies (including culture and leisure) comprise critical production functions, encompass major concentrations of the 'leading edge' or propulsive firms in key new economic sectors and offer special opportunities for social interaction and information exchange. They redefine attributes of consumption, lifestyle and urban imaginary, provide distinctive environmental amenities, and contribute to the reformation of local identity. Classification of cultural and leisure epicentres [23-25] according to spatial parameters, such as location in the urban grid, the dominant new economic activities clustered in and the 
supplementary land uses, the ways space has been produced (development, redevelopment, renewal), and the architectural and urban morphology, present three main types:

1. High-culture epicentres are usually located in conserved inner city areas and are constituted by clusters of high-culture activities such as museums of various kinds, galleries, theatres, operas, concert halls, convention centres and the like. Supplementary land uses and activities include bookshops, cafes and trendy restaurants. These epicentres are mostly produced by means of urban renewal and redevelopment. Heritage buildings are redesigned and reused, while new buildings of innovative urban morphology and architectural design are also often added to the area. As typical cases, one may refer to the Museums Quarter in Vienna, The Museums Quarter in Rotterdam, and The Museums Quarter in The Hague [13, 23-25].

2. Popular leisure epicentres are located in conserved inner city areas and constituted by clusters of leisure activities such as cafes, bars, restaurants, (ethnic and continental), popular-music clubs and the like. Supplementary land uses and activities include antique shops, fashion design shops, music shops, bookshops and avant-garde small theatres. These epicentres are mostly produced by means of urban renewal of conserved urban cores - usually former industrial or residential sites. As typical cases, one may refer to Temple Bar in Dublin, Bagladcity in Brick Lane, London, Westergas-fabriek in Amsterdam, Witte de Withstraat in Rotterdam, Psiri in Athens, and Ladadika in Thessaloniki, Greece [23-25].

3. Culture and leisure waterfront epicentres are mostly located in the heart of the inner city, but in certain cases also in the urban periphery, and are constituted by clusters of culture and leisure activities such as museums of various kinds, convention halls, galleries, concert halls, theatres, parks and promenades. Supplementary land uses and activities include housing, offices, cafes and restaurants. These epicentres mostly represent development and redevelopment schemes of innovative urban morphology and architectural design - often complemented by renewal schemes of heritage buildings and urban cores. As typical such schemes, recently developed, one may mention South Bank in London, Forum of the Cultures in Barcelona, Abandoibarra in Bilbao, Port Melbourne in Melbourne, and West Kowloon in Hong Kong [23-25].

In terms of urban morphology and architectural form, these epicentres usually exhibit a mixture of distinctive avant-garde design schemes combined with conserved and reused heritage buildings; and in this respect, they generate a new species of 'glocalised' urban landscape [26]. The term 'glocalised' is to mean a new species of urban landscape-collage dominated by two extremities: (a) that of built heritage with rather local spatial references and (b) that of design innovation having more universal or global spatial references [26].

\section{CLUSTERS OF CULTURE AND LEISURE IN GREEK CITIES: PROCESSES OF FORMATION, URBAN LANDSCAPE TRANSFORMATIONS AND THE POLICIES INVOLVED}

Since the early 1990s, Greek cities, especially Athens, the capital city, have been experiencing a constant growth of post-industrial new urban economies - information and communications technology and multimedia, culture and leisure, publishing and mass media, and intermediary financial services. Among them, culture and leisure and night-time entertainment appear to be the most developed sectors of new urban economies in Greek cities. More specifically, in respect to the total number of enterprises in all sectors of new urban economies, culture and leisure represents 55\% in Athens and $40 \%$ in Greece as a whole, while night-time entertainment reaches $29 \%$ in Athens and 50\% in Greece as a whole [27]. 
The growth of cultural and leisure economic activities in Greek cities in the last decade or so, has been accompanied with their clustering in declined inner city areas. As a catalyst, clustering has encouraged urban renewal and redevelopment and has generated whole new quarters and neighbourhoods of cultural and leisure activities - shifting the city's spatial structure, transforming urban landscape, and creating new epicentres. Most of such cultural and leisure quarters are to be found in metropolitan Greek cities, such as Athens and Thessaloniki. But they are also present in middle-sized Greek cities such as Patras, Heraklion, Volos, and others. Almost all cultural and leisure quarters have been spontaneously created and informally developed - without spatial planning and financial incentives by local authorities or the state. As typical cases of spontaneous clusters of cultural and leisure activities, we have examined (a) Pireaus Avenue in Athens, (b) the area of Ladadika in Thessaloniki and (c) the area of Palea in Volos. Table 1 presents the main characteristics of these clusters.

\subsection{Pireaus Avenue}

Pireaus Avenue was originally developed in 1835 as the main road connecting Athens to the closely neighbouring harbour city of Pireaus. Due to easy access to both cities and the harbour, most sites along Pireaus Avenue were gradually developed as industrial estates. More than a century later, in the 1970s, due to the decline of traditional industries on the one hand, and the relocation of flourishing industrial plants in properly planned industrial areas in the exurban periphery on the other hand, most of the industrial estates along Pireaus Avenue were abandoned [28]. Besides, mass national migration to Attica in the 1950s, 1960s and 1970s had entailed a rapid and dramatic demographic increase of the cities of Athens and Pireaus; and the ensuing urban expansion - mostly based on unplanned and unregulated processes - caused the merge of the two neighbouring cities in Attica. Thus, the industrial character of Pireaus Avenue became incompatible with the surrounding new residential areas. Aiming at resolving this conflict and promoting the redevelopment of this long artery $(28.5 \mathrm{~km})$, Athens' 1986 master plan enacted laws for the removal of all industries from Pireaus Avenue. As approved land uses were established housing, commercial shops, offices, restaurants, cafes and bars without live music, cultural activities, and car parking. About 170 old industrial building complexes were by law characterised and protected as built heritage. These policies accelerated the removal of all industries from Pireaus Avenue and made this artery an abandoned but protected heritage axis ready for renewal and redevelopment. Among all approved land uses and activities, culture and leisure started to spontaneously cluster in Pireaus Avenue due to its particular characteristics: (a) easy access to both Athens and Pireaus; (b) large-sized heritage edifices with great potential for redesign and reuse; (c) abandoned sites and law real estate prices; and (d) a conserved environment of high cultural value. Thus, in the last decade, Pireaus Avenue has been redeveloping as a cluster of high-culture and popular leisure. A recent land-use survey [29] has shown that very important high-culture institutions - public and private - have moved to the area. Among them, the most important are the New Benaki Museum of Modern Arts (Fig. 1); Technopolis which is administratively run by the Municipality of Athens and accommodated in the old gas-factory estate $\left(30,000 \mathrm{~m}^{2}\right)$ and hosting many music and art events in different halls and auditoriums (Fig. 2); Hellinikos Cosmos, a museum and a cultural centre run by the Foundation of Hellenic World, located in an old industrial estate $\left(60,000 \mathrm{~m}^{2}\right)$ and accommodating virtual reality shows and interactive technologyintensive education for pupils and adults, covering subjects, such as the ancient Greek history, new technologies, cyberspace and their applications (Fig. 3); The School of Fine Arts, University of Athens; Bios Centre, a multimedia art centre for innovative arts and experimental performances of all kinds hosted in an old factory of painting colours $\left(1,500 \mathrm{~m}^{2}\right)$; the Zigos art gallery and 


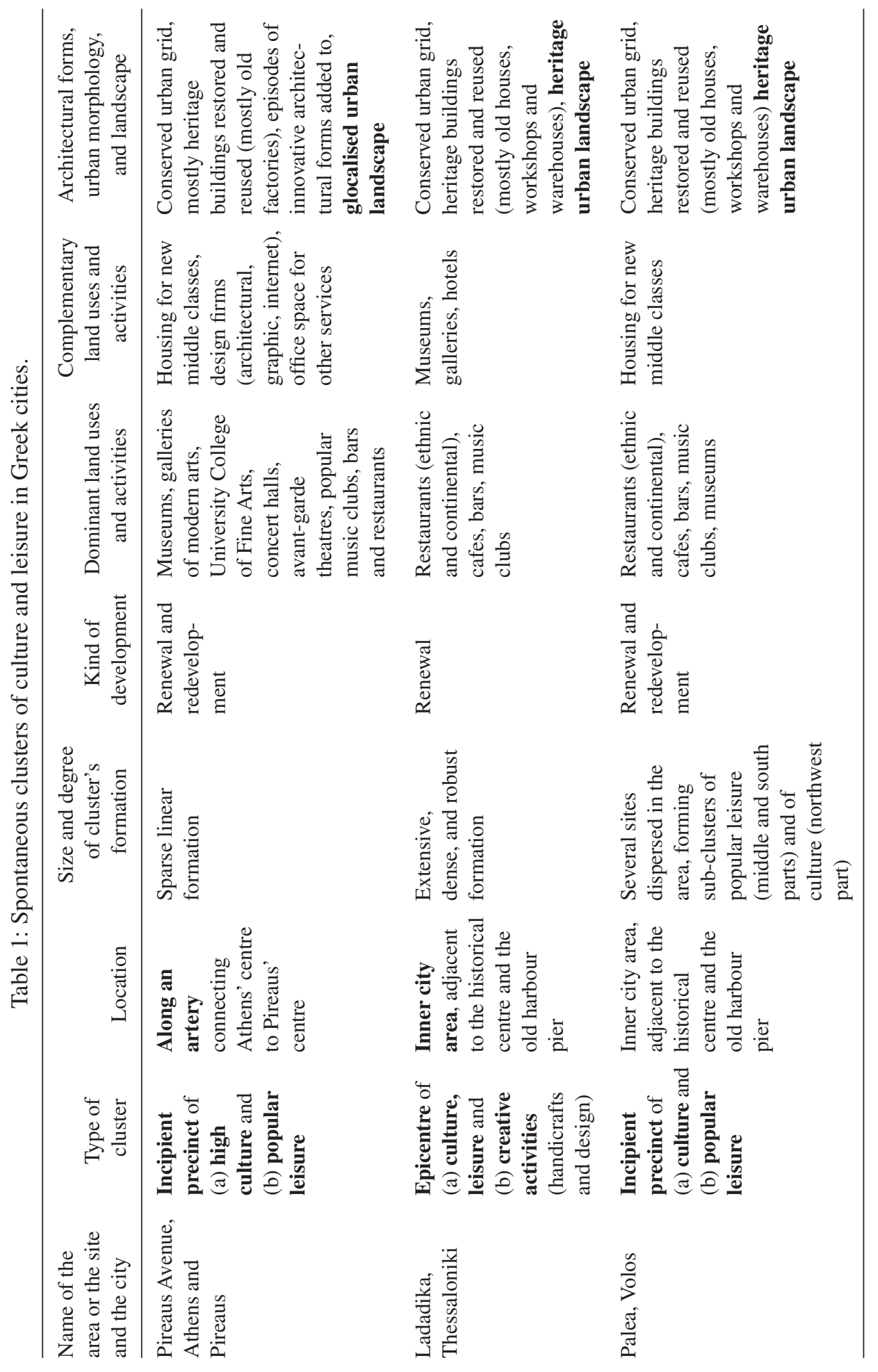




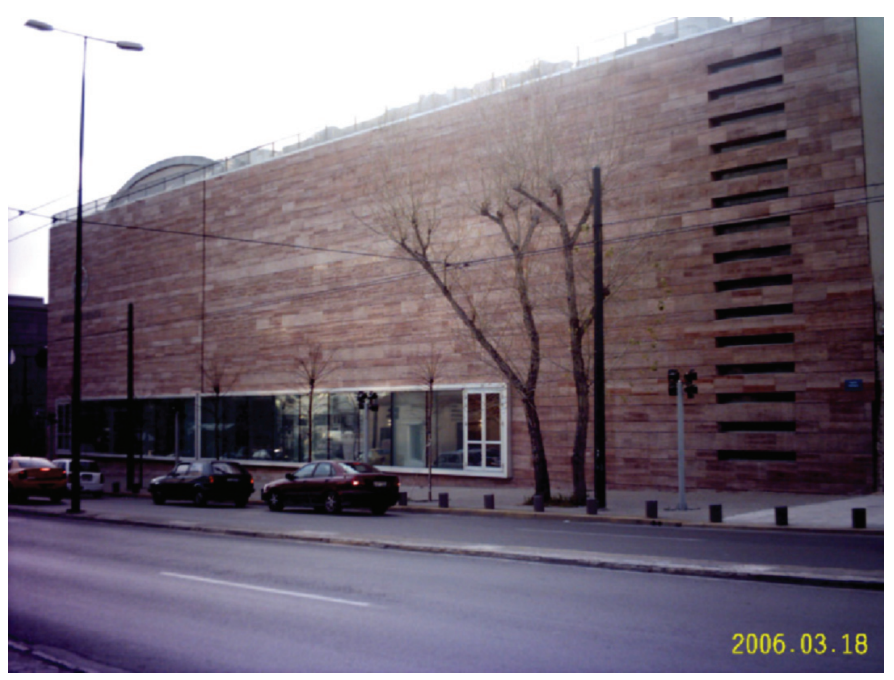

Figure 1: Pireaus Avenue, Athens: The New Benaki Museum.

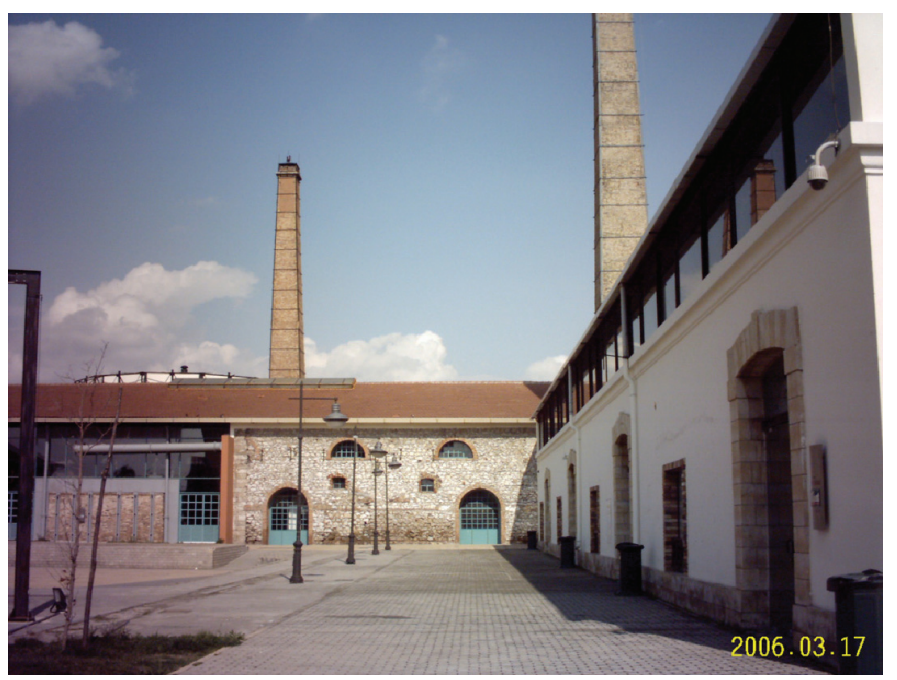

Figure 2: Pireaus Avenue, Athens: Technopolis, a complex of high culture and leisure activities, accommodated in the old gas factory and administratively run by the Municipality of Athens.

five theatres. In between these high-culture institutions and enterprises are located bars and night clubs of popular music.

\subsection{Ladadika}

Ladadika is part of the historical centre of Thessaloniki; it represents a well-preserved urban fragment of the 18th and 19th century that escaped destruction from the 1917 great fire which destroyed 


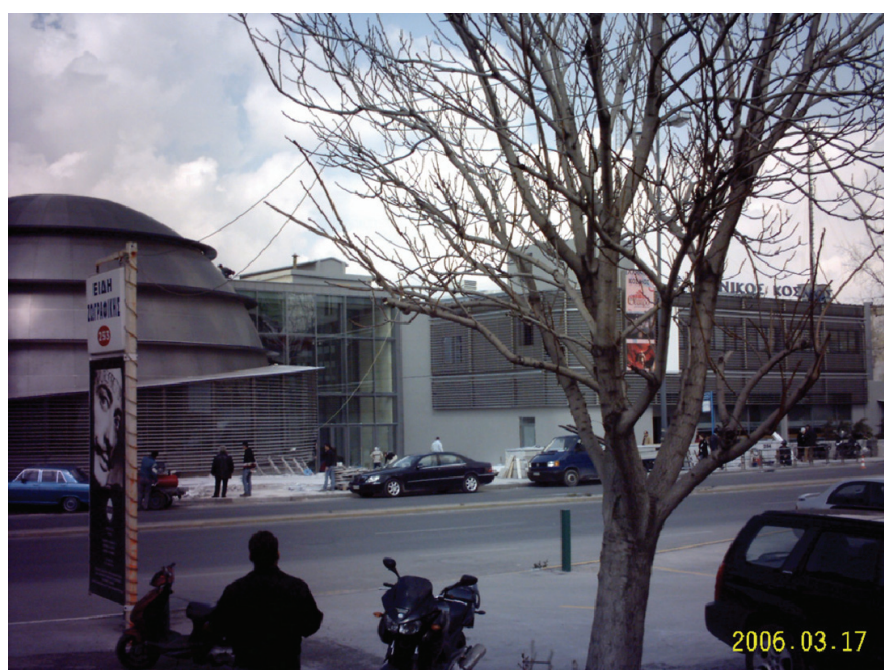

Figure 3: Pireaus Avenue, Athens: Hellinikos Cosmos, a museum and a cultural centre run by the Foundation of Hellenic World.

almost the whole historical centre of Thessaloniki. The area is adjacent to both the city's central business district (CBD) and the old central harbour pier; it was originally developed as a wholesale trade area - mainly for oil, spices and cereals - and the built fabric consisted of warehouses, workshops and commercial shops. Ladadika was a flourishing trade area until the mid-20th century. Deterioration of the area started in the 1970s - mainly due to the increasing competition with supermarkets and also due to the difficulty in accessing Ladadika by road, because it was adjacent to the CBD and also because of its narrow and tortuous streets. In the 1980s, the decay reached a peak and most of the commercial spaces in Ladadika were underused or non-used. The non-used old buildings were gradually becoming ruins, while the underused ones were also badly maintained; illegal activities (e.g. drugs smuggling, prostitution) were taking place in the area. Local authorities and the state - Municipality of Thessaloniki, Ministry of Macedonia and Thrace, and especially the local Urban Planning Division of Ministry of Environment, Planning and Public Works - made coordinated efforts for the renewal and regeneration of Ladadika [30, 31]. The area was recognised by law as a heritage urban core; and both public open spaces (including streets, squares, and the like) and 87 old buildings were protected by law as built heritage that ought to be conserved. In the late 1980s and the early 1990s, the EU and the Greek state funded through the programme of Urban Pilot Projects, the conservation and renewal of 21 private buildings of high cultural value, as well as the renewal of all public open spaces in Ladadika (see Fig. 4). However, shortage of public funds favoured the decision to set a strict regulation framework for the conservation and renewal of the remaining private heritage buildings, leaving the financing to private interests - the new tenants of the area. Besides, the fear of failing to attract private funds fast on the one hand, and the ongoing deterioration of private heritage buildings on the other, forced planners and local authorities to abandon their original intention to strictly control land uses in the area and provide incentives for high-culture activities (museums, galleries, etc.) and commerce. Thus, popular leisure enterprises (such as cafes, bars, restaurants, music clubs and the like), which were the most affluent enterprises interested to settle in the area, started to invest in the conservation and renewal of heritage buildings 


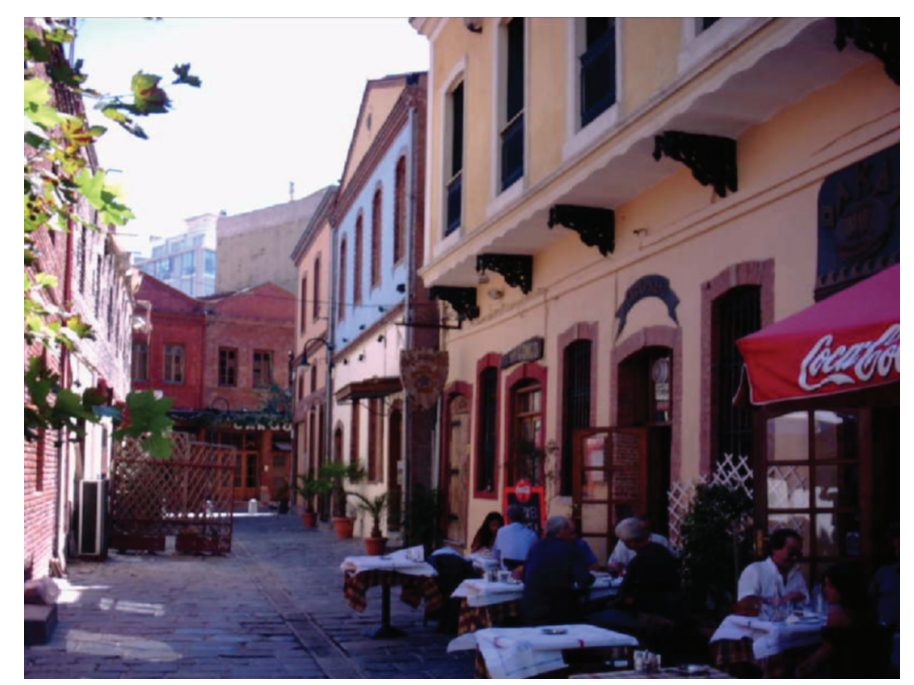

Figure 4: Ladadika, Thessaloniki: A typical street with heritage buildings, housing cafes/bars, and so on.

and gradually congregate in Ladadika. In a course of a decade or so, Ladadika was spontaneously transformed into a cluster of cultural and leisure activities.

Recent land-use survey [32] has shown that culture and leisure economic activities cover 39.69\% of the total surface of built space in Ladadika (see Table 2). However, the area's development prospects as a cluster of culture and leisure appear blurred, since there are today a lot of vacant spaces $(10.87 \%)$ in renewed heritage buildings that were earlier occupied. Moreover, between 2003 and 2006, the balance between new cultural and leisure enterprises settled in Ladadika and similar enterprises shutting down in the area is just slightly positive. According to data provided by Commercial Chamber of Thessaloniki, in the period 2003-06, 40 new cultural and leisure enterprises appeared while 36 closed.

\subsection{Palea}

Palea is the historical core of the town of Volos. Archaeological excavations in different sites in the area of Palea have identified and partly revealed various levels of archaeological ruins belonging to settlements established one over the other in different historical periods - from pre-history to the Ottoman period. These are an agricultural settlement of the Copper Age (3000 BC); an agricultural settlement of the Bronze Age (1900-1550 BC); an urban settlement of the Mycenaean period (1550$1000 \mathrm{BC}$ ); an urban settlement of the Iron Age between the 10th and the 7th centuries BC; a city-state (polis) of Classical Antiquity (5th and 4th centuries BC); a medieval settlement, as well as remnants of defence walls of the Byzantine period and the Ottoman period. Besides, remnants of the Byzantine and Ottoman walls that have been preserved and conserved now constitute important historical monuments accessible to visitors. Most parts of the walls were demolished, together with the organic street pattern of the Ottoman settlement in Palea, following the 1883 master plan which arranged space so as the new town of Volos in the east and the old fenced settlement in Palea would be integrated into one modern city with a grid-iron street pattern. The implementation of the 1883 plan 
Table 2: The cluster of cultural, leisure and creative activities in Ladadika, Thessaloniki.

\begin{tabular}{|c|c|c|c|c|}
\hline Land uses & $\begin{array}{l}\text { Total number } \\
\text { of enterprises }\end{array}$ & $\begin{array}{l}\text { Total surface } \\
\text { covered by } \\
\quad\left(\mathrm{m}^{2}\right)\end{array}$ & $\begin{array}{l}\text { Mean surface } \\
\text { covered by } \\
\left(\mathrm{m}^{2}\right)\end{array}$ & $\begin{array}{l}\text { Percentage of the total } \\
\text { surface covered by } \\
\text { economic activities } \\
\text { in Ladadika }(\%)\end{array}$ \\
\hline $\begin{array}{l}\text { Popular leisure (cafes, } \\
\text { bars, restaurants, music } \\
\text { clubs, etc.) }\end{array}$ & 59 & $7,959.81$ & 134.86 & 10.91 \\
\hline $\begin{array}{l}\text { High culture (museums, } \\
\text { art galleries, ballet } \\
\text { schools, colleges) }\end{array}$ & 4 & 2,319 & 579.75 & 3.18 \\
\hline $\begin{array}{l}\text { Creative activities: (a) } \\
\text { design firms (architectural } \\
\text { design, graphics, software } \\
\text { design, internet services); } \\
\text { (b) handicraft shops and } \\
\text { workshops }\end{array}$ & 39 & $9,917.42$ & 254.29 & 13.60 \\
\hline $\begin{array}{l}\text { Other services related to } \\
\text { culture and leisure } \\
\text { (tourism agencies, hotels) }\end{array}$ & 15 & 8,741 & 582.73 & 12 \\
\hline $\begin{array}{l}\text { Total for all cultural, } \\
\text { leisure and creative } \\
\text { activities }\end{array}$ & 117 & $28,937.23$ & 387.91 & 39.69 \\
\hline $\begin{array}{l}\text { Services and commercial } \\
\text { activities not related to } \\
\text { culture and leisure (e.g. } \\
\text { bank branches, consultant } \\
\text { bureaus of engineers, } \\
\text { solicitors, customs } \\
\text { clearing bureaus, shipping } \\
\text { companies, marine shops) }\end{array}$ & 57 & 35,550 & 623.68 & 48.75 \\
\hline $\begin{array}{l}\text { Total for all economic } \\
\text { activities in the cluster }\end{array}$ & 174 & $64,487.23$ & 435.06 & 88.44 \\
\hline $\begin{array}{l}\text { Space vacancies in } \\
\text { renewed heritage buildings } \\
\text { earlier occupied }\end{array}$ & 24 & 7,928 & 330.33 & 10.87 \\
\hline $\begin{array}{l}\text { Non-used spaces in } \\
\text { heritage buildings not } \\
\text { renewed yet }\end{array}$ & 7 & 506.72 & 72.39 & 0.69 \\
\hline Total & & $72,918.90$ & & 100 \\
\hline
\end{tabular}


radically changed the morphological and spatial character of Palea. However, due to the neighbouring of the area to both the harbour and the railway station, Palea quickly acquired a new character as an industrial and wholesale area: a large number of small and large industries, workshops, warehouses, wholesale trade, and commercial activities developed in the area in the first decades of 20th century [33].

After the catastrophic earthquakes in 1955, the majority of buildings in the town of Volos, including Palea, were largely damaged. The area was reconstructed in the 1960s as a low-middle class residential area (central part) but lost part of its industrial and commercial activities (northern and southern parts), which were relocated in the industrial zone at the outskirts of the Volos. The deterioration of the area continued in the 1970s as a result of (a) the decline of traditional industries; (b) the disconnection of Palea from the fast developing CBD in the central-east part of the city due to the railways boundaries; (c) the decline of small family workshops and commercial shops in virtue of the increasing competition with large commercial shops in CBD; and (d) restrictions in the reconstruction of sites due to archaeological ruins and their protection. Deterioration processes lasted for more than two decades; and a large number of old industrial buildings, warehouses, workshops, and commercial shops were abandoned. The 1992 plan of Volos recognised Palea as a historical urban core requiring renewal and regeneration. Local authorities made efforts to expand the CBD towards the west and regenerate Palea by moving departments of public services and municipal cultural activities to abandoned old industrial buildings in and around the area of Palea. Among them, the most significant is the old Tsalapata factory which has been redesigned and reused as a museum of industrial heritage (Fig. 5).

However, it was neither the state nor local authorities but the dynamic market of night-time entertainment and private funds that steered urban renewal and regeneration in Palea. Since the mid-1990s, enterprises such as cafes, bars, music clubs, restaurants and the like started to gradually settle in the area while conserving and reusing abandoned heritage edifices, thus, impelling the formation and development of a cluster of popular leisure in the central and southern parts of Palea. Cultural activities, such as multiplex cinemas and shopping centres, art galleries, and a radio-television channel,

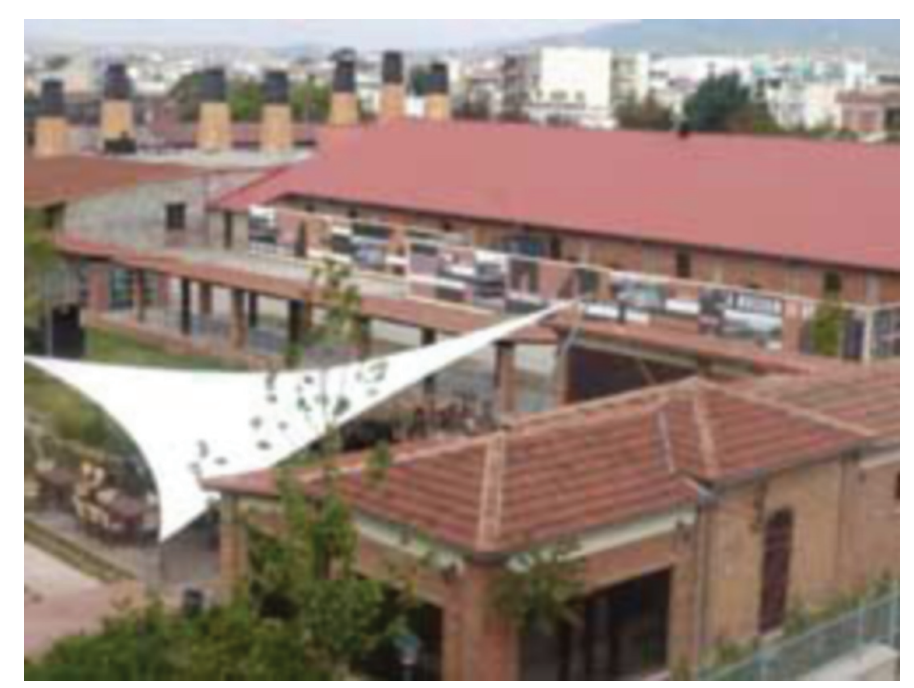

Figure 5: Palea, Volos: Tsalapata Museum of industrial heritage. 
Table 3: The cluster of culture, leisure, and creative activities in Palea, Volos.

\begin{tabular}{|c|c|c|c|c|}
\hline Land uses & $\begin{array}{l}\text { Total number } \\
\text { of enterprises } \\
\text { (or/and } \\
\text { spatial } \\
\text { compartments) }\end{array}$ & $\begin{array}{c}\text { Total } \\
\text { surface } \\
\text { covered by } \\
\left(\mathrm{m}^{2}\right)\end{array}$ & $\begin{array}{c}\text { Mean } \\
\text { surface } \\
\text { covered by } \\
\left(\mathrm{m}^{2}\right)\end{array}$ & $\begin{array}{l}\text { Percentage of the } \\
\text { total surface } \\
\text { covered by } \\
\text { economic } \\
\text { activities in } \\
\text { Palea }(\%)\end{array}$ \\
\hline $\begin{array}{l}\text { Popular leisure (cafes, bars, } \\
\text { restaurants, music clubs, etc.) }\end{array}$ & 44 & $8,033.5$ & 182.58 & 8.58 \\
\hline $\begin{array}{l}\text { Culture } \\
\text { (museums, art galleries, } \\
\text { multiplex cinemas ballet school, } \\
\text { radio-television channels) }\end{array}$ & 7 & 16,225 & $2,317.86$ & 17.07 \\
\hline $\begin{array}{l}\text { Creative activities: Design firms } \\
\text { (architectural design, graphics, } \\
\text { software design, foreign } \\
\text { languages school, publishing) } \\
\text { Handicraft shops and } \\
\text { workshops (traditional metal } \\
\text { workshops, hand-made furniture) }\end{array}$ & 9 & 896 & 99.5 & 0.94 \\
\hline $\begin{array}{l}\text { Commerce related to culture and } \\
\text { leisure (music shops, wine cellars, } \\
\text { photo shops, traditional hand-made } \\
\text { furniture) }\end{array}$ & 5 & 403 & 80.6 & 0.42 \\
\hline $\begin{array}{l}\text { Total for all cultural, leisure, and } \\
\text { creative activities in the cluster }\end{array}$ & 65 & $25,557.5$ & 670.14 & 27.01 \\
\hline $\begin{array}{l}\text { Other services and commercial } \\
\text { activities not related to culture and } \\
\text { leisure (e.g. banks' branches, } \\
\text { consultant bureaus of engineers, } \\
\text { solicitors, customs clearing } \\
\text { bureaus, shipping companies, } \\
\text { marine shops) }\end{array}$ & 181 & $29,767.5$ & 162.67 & 31.31 \\
\hline Residence & 435 & 29,443 & 67.68 & 30.97 \\
\hline $\begin{array}{l}\text { Total for all land uses and } \\
\text { economic activities in the cluster }\end{array}$ & 681 & 84,768 & 229.47 & 89.29 \\
\hline $\begin{array}{l}\text { Non-used spaces in heritage } \\
\text { buildings not renewed yet }\end{array}$ & 65 spaces & 10,298 & 158.43 & 10.71 \\
\hline Total & 746 & 95,066 & 219.32 & 100 \\
\hline
\end{tabular}


followed night-time entertainment and created a sub-cluster of culture and leisure in the northern part of Palea. Recent land-use survey (see [34] and Table 3) has shown that at present $27.01 \%$ of the total built-up area is covered by cultural, leisure and creative activities. Among them, culture is most developed in terms of surface covered (17.07\%), while popular leisure and night-time entertainment are dominant in terms of the number of enterprises (44 out of 65).

\section{CONCLUSIONS: CLUSTERS OF CULTURE AND LEISURE IN MATURE AND DEVELOPING EUROPEAN CITIES - THEIR CHARACTERISTICS AND DEGREE OF SUSTAINABILITY}

Culture and leisure undoubtedly constitute the growth engine of urban economy in the post-industrial era; and this applies to all classes and groups of cities - from global cities and economically mature large cities in Europe and North America to developing large Mediterranean cities in south and southeast Europe, as well as cities of growth economies in southeast Asia and Australia. However, the formation and developing processes of clusters of cultural and leisure activities seem to create significant differences among groups of cities.

As already described in the introduction, global cities and mature large cities appear to support and control the formation, development, and management of such clusters by means of spatial planning, architectural and urban design and local policies. This is the case for instance, Vienna's and Rotterdam's Museum quarters; Barcelona's Forum of Civilisations 2004 - a new waterfront complex at the periphery of the city hosting cultural activities from all over the world. Even smaller European cities appear to exhibit successful examples of new cultural and leisure neighbourhoods that have been comprehensively planned, designed and managed, such as Bilbao's Abandoibarra area along Nervion River and Valencia's City of Arts and Sciences. All these clusters have also been hardbranded [35] by means of innovative design schemes - products of design competitions or contracts with pioneer architects - enhancing the identity of such epicentres. As such examples may be mentioned, the Momuk (Museum Modern Kunst) in Vienna and NAI (Netherlands Architecture Institute) in Rotterdam, Ghery's Guggenheim Museum in Bilbao, or Calatrava's L' Hemispheric in Valencia; innovative design schemes are in certain cases added to the existing heritage built fabric, thus, generating a kind of 'glocal' urban landscape in the cluster [26].

In contrast to the above, the Greek experience shows that epicentres of high-culture and leisure, like that of Pireaus Avenue in Athens, are characterised by spontaneous formation and laissez-faire development and management. Interviews [29] with directors of high-culture enterprises (e.g. museums, art galleries, and the like), as well as the managerial personnel of night-time entertainment enterprises located in the area of Pireaus Avenue, have shown a low interest of local authorities and the state in both the formation and development processes of the cluster. Interviewees remonstrated about the following: First, renewal or/and redevelopment processes in heritage industrial estates both public and private - exhibit a slow pace since no economic incentives have been established by local authorities or the state. Second, there are public open spaces on Pireaus Avenue that have not yet been renewed, whereas those redesigned and reconstructed are not decently maintained, but they often constitute no go spaces [18], i.e. they are dangerous spaces with high criminality during late night. Third, public transportation along Pireaus Avenue is not satisfactory. Fourth, there is still a law banishing the functioning of clubs and restaurants with live music on Pireaus Avenue, although such enterprises have been flourishing in the area almost a decade now and are still illegally operating without a proper licence. Fifth, interviewees expressed their wish for a possible cooperation in the cluster to host mega cultural events, distributed all over the various building complexes. 
In the case of popular leisure clusters, differences are also significant between mature cities and Mediterranean large cities. Mature cities appear to imply incentives encouraging the formation and development of such clusters. As Hitters and Richards [17] argue through the analysis of Witte de Withstraat in Rotterdam and Westrgasfabriek in Amsterdam, the particular management approach adopted by local authorities to the renewal and transformation processes of such conserved urban cores into popular leisure epicentres may have critical results in the variety of functions and activities clustered, the cluster's degree of creativity as incubation space, the image of the area, and place identity. However, the Greek experience shows also in this case, a spontaneous formation and a kind of a 'laissez-faire' development. For instance, the lack of land-use control by local authorities in the case of Ladadika, as earlier described, has finally entailed the cluster's mono-functional identity activities almost exclusively confined to cafes, bars, restaurants - and thereby a low degree of creativity and perhaps a low degree of sustainability. As a first sign of decay in the area, one may note that during the last years, the number of enterprises opening and the number of those closing in Ladadika are almost equal. Interviews [32, 34] with managerial personnel of night-time entertainment enterprises located in the areas of Ladadika and Palea has revealed the lack of strong efforts and special policies by local authorities. Interviewees complained about the lack of financial incentives for attracting high-culture institutions and activities, the conditions of maintenance of public open spaces, and the delay of renewal processes in the very few heritage buildings that have not yet renewed ( $0.69 \%$ of the total built-up area).

All of the above highlight the inefficiency of local authorities in some Mediterranean cities in southeast Europe to: (a) invest in planning and design of new cultural and leisure epicentres: and (b) produce local policies for their formation, development and management [36, 37]. Possible shortage of finance may not always explain the established 'laissez-faire' practices; it seems that there is also a lack of understanding about the characteristics of the post-industrial era, the profile of the growing post-modern societies, the growth potential of cultural and leisure economies, and the critical importance of the new epicentres in the development prospects of cities in the new era. However, in the framework of the increasing intercity competition and the fast growing new urban economies, Mediterranean cities like Greek cities have to launch new strategies following what Mommas [13] has called a shift towards creating quarters and milieus for cultural production and creativity.

\section{REFERENCES}

[1] Bianchini, F., Culture, conflict and cities: issues and prospects for the '90s. Cultural Policy and Urban Regeneration: The West European Experience, eds F. Bianchini \& M. Parkinson, Manchester University Press: Manchester, 1993.

[2] Zukin, S., The Cultures of Cities, Blackwell Publishers Ltd: Cambridge, MA, 1995.

[3] Lash, S. \& Urry, J., Economies of Signs and Space, Sage: New York, 1994.

[4] Castells, M., The Rise of the Network Society, Blackwell: Oxford and Malden, 1996.

[5] Scott, A.J., The cultural economy of cities. International Journal of Urban and Regional Research, 21(2), pp. 323-339, 1997.

[6] Scott, A., The Cultural Economy of Cities, Sage: London, 2000.

[7] Hall, P., Creative cities and economic development. Urban Studies, 37(4), pp. 639-649, 2000.

[8] Crompton, J.L. \& Mackay, S.L., Measuring the economic impact of festivals and events; some myths, misapplications and ethical dilemmas. Festival Management and Event Tourism, 2(1), pp. 33-34, 1994. 
[9] Pratt, A.C., The cultural industries sector: its definition and character from secondary sources on employment and trade - Britain 1984-91, Research Papers on Environmental and Spatial Analysis, No. 41, London School of Economics, 1997.

[10] Hobbs, D., Lister, S. \& Hadfield, Ph., Receiving shadows: governance and liminality in the night-time economy. British Journal of Sociology, 51(4), pp. 701-717, 2000.

[11] Hollands, R. \& Chatterton, P., Producing nightlife in the new urban entertainment economy: corporatization, branding and market segmentation. International Journal of Urban and Regional Research, 27(2), pp. 361-385, 2003.

[12] Clark, T.N., Lloyd, R., Wong, K.K. \& Jain, P., Amenities drive urban growth. Journal of Urban Affairs, 24(5), pp. 493-515, 2002.

[13] Mommaas, H., Cultural clusters and the post-industrial city: towards the remapping of Urban cultural policy. Urban Studies, 41(3), pp. 507-532, 2004.

[14] Krätke, S., Network analysis of production clusters: the Potsdam/Babelsberg Film Industry as an example. European Planning Studies, 10(1), pp. 27-54, 2002.

[15] Bassett, K., Griffiths, R. \& Smith, I., Cultural industries, cultural clusters and the city: the example of natural history film-making in Bristol. Geoforum, 33, pp. 165-177, 2002.

[16] Turok, I., Cities, clusters and creative industries: the case of film and television in Scotland. European Planning Studies, 11(5), pp. 549-565, 2003.

[17] Hitters, E. \& Richards, G., The creation and management of cultural clusters. Creativity and Innovation management, 11(4), pp. 234-247, 2002.

[18] Roberts, M., From 'creative city' to 'no-go areas' - the expansion of night-time economy in British town and city centres. Cities, 23(5), pp. 331-338, 2006.

[19] Crewe, L., Material culture: embedded firms, organizational networks and the local economic development of a fashion quarter. Regional Studies, 30(3), pp. 257-272, 1996.

[20] Creigh-Tyte, A., Measuring creativity: a case study in the UK's designer fashion sector. Cultural Trens, 14(2), pp. 157-183, 2005.

[21] Shaw, S., Bagwell, S. \& Karmowska, J., Ethnoscapes as spectacle: reimaging multicultural districts as new destinations for leisure and tourism consumption. Urban Studies, 41(10), pp. 1983-2000, 2004.

[22] Hutton, Th.A., The new economy of the inner city. Cities, 21(2), pp. 89-108, 2004.

[23] Gospodini, A., Portraying, classifying and understanding the emerging new landscapes in the post-industrial city. Cities, 23(5), pp. 311-331, 2006.

[24] Gospodini, A., Landscape transformations in the post-modern inner city: clustering flourishing economic activities and 'glocalising' morphologies. Proceedings of the International Conference on Sustainable Planning and Development, Bologna, 12-14 September 2005, pp. $1469-1485,2005$.

[25] Gospodini, A. \& Beriatos, E., (eds), New Urban Landscapes and the Greek City, Kritiki Publications: Athens, 2006 (in Greek).

[26] Beriatos E., \& Gospodini, A., Glocalizing urban landscapes - Athens and the 2004 Olympics. Cities, 21(3), pp. 187-202, 2004.

[27] Gospodini, A., Post-industrial trajectories of Mediterranean European cities. Learning from post-Olympics Athens and the Greek experience. Urban Studies, Trajectories of the New Economy: An International Investigation of Inner City Regeneration and Dislocation, theme issue, 2007 (forthcoming).

[28] Sariyannis, G., Athens 1830-2000: Urban Development, Planning and Transports, Symmetry Editions: Athens, 2000 (in Greek). 
[29] Papadema, P., Pireaus Avenue, Athens: investigating the formation and management of the cluster of new economies, Student research project, Department of Planning and Regional Development, University of Thessaly, Volos, Greece, 2006.

[30] Voulgaris, A., Prospects and Potentials of Applying Programmes of Urban Renewal in the Contemporary Greek City' (in Greek), also translated in Italian as 'Prospettive e possibilita di applicazione dei programme di recupero urbano nella citta grace contemporanea'. Programma Heracles, Le sfide della citta greca, eds F. Infussi, \& Y. Simioforides, Linora: Athens, pp. 170-179, 1998.

[31] Mavromatis, M., Ladadika: From Abandonment to Conservation and Regeneration, Report, Direction of Environment and Planning, Division of Central Macedonia, Ministry of Environment, Planning and Public Works, 1995.

[32] Koukoulis, G., The Cultural and Leisure Cluster in Ladadika, Thessaloniki: Investigating the Spatial and Economic Parameters, Diploma Thesis, Department of Planning and Regional Development, University of Thessaly, Volos, Greece, 2006.

[33] Hastaoglou, V., Volos: The portrait of the city in the 19th and 20th centuries, Municipality of Volos Publications: Volos, 2002 (in Greek).

[34] Papadema, P., Palea, Volos: The transformation of the area into a cluster of cultural and leisure activities, MSc Thesis, Department of Planning and Regional Development, University of Thessaly, Volos, Greece, 2006.

[35] Evans, G., Hard-branding the cultural city - from Prado to Prada. Journal of Urban and Regional Research, 27(2), pp. 417-440, 2003.

[36] Leontidou, L., Post-modernism and the city: Mediterranean versions. Urban Studies, 30(6), pp. 949-965, 1993.

[37] Leontidou, L., Multi-culture and heterotopia in the Mediterranean urban landscape: from spontaneous urbanisation to the entrepreneurial city. New Urban Landscapes and the Greek City, eds A. Gospodini \& E. Beriatos, Kritiki Publications: Athens, pp. 70-84, 2006 (in Greek). 